\title{
TINJAUAN YURIDIS TENTANG SISTEM PERADILAN PIDANA
}

\author{
Oleh : Ida Rahma ${ }^{1}$
}

\begin{abstract}
Abstracs
The function of criminal law aims to prevent future crimes in order to prevent the occurrence of criminal countermeasures. The criminal itself is a sanction or a sorrow that tells. Criminal law is a rule of law or a set of rules or legal norms that regulate an act which is a criminal act, when an act is declared as a criminal act and set the effect (witness) given in reaction to the act that violates the rule of criminal law. The function of the criminal law itself is to provide a criminal to those who violate the penal law through state equipment, in order to maintain public order. Law enforcement is the activity of harmonizing relationships of values that are outlined in the rules and attitude of acts as a series of the final value of the termination to create as social enginering, maintaining and maintaining as the social control of social interaction, whether it is a preventive action (preventive) ) As well as acts of eradication (repressive).
\end{abstract}

\section{Kata Kunci: Hukum Pidana, Sistem Hukum Pidana.}

\section{A. Tindak Pidana Menurut Hukum Positif di Indonesia}

Hukum pidana adalah salah satu bagian dari norma atau kaidah yang mengatur kehidupan masyaarakat mengandung berbagai pengertian yang bermacam-macam. Dalam menentukan pengertian hukum pidana menurut ilmu pengetahuan, dapat dibedakan dalam berbagai golongan pendapat:Hukum pidana adalah sanksi.Definisi ini diberikan dengan lapangan hukum yang lain yaitu bahwa hukum pidana sebenarnya tidak mengadakan norma sendiri melainkan sudah terletak dalam lapangan hukum lain, dan sanksi pidaa yang diadakan untuk menguatkan ditaatinya norma-norma diluar hukum pidana.Hukum pidana adalah keseluruhan aturan ketentuan hukum mengenai perbuatan-perbuatan yang dapat dihukum dan aturan pidananya.

Hukum pidana dalam arti:Objek (Ius Poenale) meliputi:Perintah dan larangan yang pelanggarannya diancam dengan sanksi pidana oleh badan yang berhak.Ketentuan-ketentuan yang mengatur upaya yang dapat dipergunakan,

\footnotetext{
${ }^{1}$ Alumni S2 Magister Ilmu Hukum Universitas Syiah Kualah Dosen pada prodi Hukum Tata Negara STAIN Teungku Dirundeng Meulaboh
} 
apabila norma itu dilanggar. Dan aturan-aturan yang menentukan kapan dan dimana berlakunya norma-norma tersebut diatas.

Hukum pidana dalam arti Subyektif (Ius Punendi) yaitu hak negara menurut hukum untuk menentukan pelanggar delik dan untuk menjatuhkan serta melaksanakan pidana. Hukum pidana dibedakan dan diberikan arti sebagai hukum pidana materil dan formil:

1. Hukum pidana materiil yang menunjuk pada perbuatan pidana dan yang oleh sebab perbuatan itu dapat dipidana, dimana perbuatan pidana (Strafbare Feit) itu mempunyai dua bagian yaitu:

a. Bagian objektif merupakan suatu perbuatan atau sikap (nalaten) yang bertentangan dengan hukum positif, sehingga bersifat melawan hukum yang menyebabkan tuntutan hukum dengan ancaman pidana.

b. Bagian subjektif merupakan suatu kesalahan, yang menuntut kepada si pembuat (dader) untuk dipertanggungjawabkan menurut hukum.

2. Hukum pidana formil yang mengatur cara hukum pidana materiil dapat dilaksanakan.Hukum pidana diberikan arti bekerjanya sebagai; Pertama, Peraturan hukum objektif (Ius Poenale) yang dibagi lagi menjadi: Pertama hukum pidana materiil yaitu peraturan tentang syarat-syarat bilamanakah, siapakah, bagaimanakah sesuatu itu dapat dipidana. Kedua, Hukum pidana formil yaitu hukum acara pidananya; Ketiga, Hukum Subjektif (Ius Punendi) yaitu meliputi hukum yang memberikan kekuasaan untuk ancaman pidana, menetapkan putusan dan melaksanakan pidana hanya dibebanka kepada negara atau pejabat yang ditunjuk untuk itu. ${ }^{2}$

Fungsi hukum pidana bertujuan mencegah dilakukannya kejahatan pada masa yang akan datang dalam upaya mencegah terjadinya penanggulangan tindak pidana. Pidana itu sendiri merupakan suatu sanksi atau nestapa yang 20.

2 Bambang Poernomo, Asas-asas Hukum Pidana, (Jakarta : Ghalia Indonesia, tt), hlm.19- 
menderitakan. Dalam penerapannya, fungsi hukum pidana terbagi menjadi dua yaitu:

1. Fungsi Umum Hukum Pidana, untuk mengatur hidup kemasyarakatan atau menyelenggarakan tata kehidupan masyarakat.

2. Fungsi Khusus Hukum Pidana, untuk melindungi kepentingan hukum dari perbuatan yang hendak memperkosanya dengan sanksi pidana yang sifatnya lebih tajam dari sanksi cabang hukum lainnya. ${ }^{3}$

Berdasarkan uraian tersebut di atas dapat diketahui bahwa hukum pidana merupakan aturan hukum atau seperangkat kaidah atau norma hukum yang mengatur tentang suatu perbuatan yang merupakan perbuatan pidana, kapan suatu perbuatan dinyatakan sebagai perbuatan pidana serta menetapkan akibat (saksi) yang diberikan sebagai reaksi terhadap perbuatan yang melanggar aturan hukum pidana tersebut. Fungsi hukum pidana itu sendiri adalah untuk memberikan pidana kepada yang melanggar hukum pidana melalui alat-alat perlengkapan negara, dalam menjaga ketertiban masyarakat.

Penegakan hukum adalahKegiatan menyerasikan hubungan nilai-nilai yang terjabarkan dalam kaidah-kaidahdan sikap tindak sebagai rangkaian penjabaran nilai tahap akhir untuk menciptakan sebagai social enginering, memelihara dan mempertahankan sebagai social controlkedamaian pergaulan hidup, ${ }^{4}$ baik merupakan tindakan pencegahan (preventif) maupun tindakan pemberantasan (represif).

Salah satu ketentuan yang mengatur bagaimana caranya aparatur penegak hukum melaksanakan tugas dibidang represif adalah hukum acara pidana yang mempunyai tujuan yaitu untuk mencari dan mendekati kebenaran materiil.

Dalam acara pemeriksaan cepat, keyakinan hakim cukup didukung oleh satu alat bukti yang sah. Dengan kata lain, walaupun hanya didukung oleh satu alat bukti yang sah, dan hakim yakin atas kesalahan terdakwa maka terdakwa tersebut dapat dihukum.Dengan demikian hakim baru boleh menghukum se-

${ }^{3}$ Moeljatno, Asas-Asas Hukum Pdana, (Jakarta : Rineka Cipta, 1993), hlm.1

${ }^{4}$ Purnadi Purbacaraka, Penegakan hukum dalam mensukseskan pembangunan BPKH Lampung, dikutip dari Soerjono Soekanto, Penegakan Hukum, (Banding : Binacipta, 1983), hlm. 13. 
seorang terdakwa apabila kesalahannya terbukti secara sah menurut undangundang. Keterbuktian itu harus pula diperkuat dan didukung oleh keyakinan hakim., namun apabila hakim tidak berkeyakinan atas kesalahan terdakwa maka terdakwa tersebut harus dibebaskan. Sesuai dengan Pasal 1 butir 9 KUHAP sejalan dengan tugas hakim dalam pengadilan pidana yaitu mengadili dalam arti menerima, memeriksa dan memutus perkara pidana berdasarkan asas bebas, jujur dan tidak memihak disidang Pengadilan.

Menurut Pasal 194 HIR - sekarang Pasal 183 KUHAP menyatakan bahwa Undang-undang selalu menempatkan keyakinan hakim sebagai suatu kunci terakhir dalam pemeriksaan pengadilan dipersidangan. Keyakinan hakim memegang peranan yang tidak kalah pentingnya dengan upaya-upaya bukti yang diajukan dipersidangan, bahkan keyakinan hakim diletakkan oleh pembuat undang-undang ditingkat teratas. Karena berapapun saja upaya bukti yang diajukan dipersidangan mengenai suatu tindak pidana, kalau hakim tidak yakin atas kesalahan (kejahatan) yang dituduhkan kepada terdakwa, maka terdakwa tidak dapat dihukum, berarti dibebaskan (vrijspraak) atau setidak-tidaknya dilepaskan (ontslag). ${ }^{5}$

Faktor keyakinan yang memberi bobot dan sekaligus ciri pada prinsipprinsip kekuasaan kehakiman yang merdeka, peradilan yang bebas dan kebebasan hakim dalam mengenai perkara yang disidangkan.

Fungsi utama dari hukum acara pidana adalah tidak lain dari pada merekontrucer kembali kejadian-kejadian dari seorang pelaku dan perbuatannya yang dilarang, sedangkan alat-alat pelengkap dari pada usaha tersebut adalah barang bukti. Pelaku, perbuatannya dan barang bukti merupakan suatu kesatuan yang menjadi fokus dari pada usaha mencari dan menemukan kebenaran materiil. Terhadap pelaku harus dibuktikan bahwa ia dapat dipertanggungjawabkan secara pidana (toerekenbaar) disamping bukti tentang adanya kesalahan (schuld), dan

5 Majalah Hukum, Sangkakala Peradilan, Tahun Ke III No.9, 1973. Semarang : Ikatan Hakim Indonesia (IKAHI), 1973), hlm.4, dikutip dari Abdullah Sani, Hakim dan Keadilan Hukum. hlm. 59. 
AL-QADHA Jurnal Hukum Islam Dan Perundang-undangan

terhadap perbuatannya apakah terbukti sifat melawan hukum (wederrechtelijkheid) dari perbuatan itu. ${ }^{6}$

\section{B. Pengertian Tindak Pidana}

Tindak pidana merupakan suatu pengertian dasar dalam hukum pidana dan oleh karena itu memahami tindak pidana adalah sangat penting. Tindak pidana merupakan suatu pengertian yang yuridis, lain halnya dengan kejahatan yang bisa diartikan secara yuridis ataupun krimonologis. Istilah tindak pidana adalah terjemahan dari bahasa Belanda yaitu "strafbaar feit "atau "delict".

Beberapa sarjana menyatakan pengertian tentang perbuatan pidana, tindak pidana, ataupun strafbaar feit yang akan diuraikan sebagai berikut :

1. R. Soesilo mendefinisikan tindak pidana sebagai suatu perbuatan yang dilarang atau diwajibkan undang-undang yang apabila dilakukan atau diabaikan, maka orang yang melakukan atau mengabaikan itu diancam dengan pidana. $^{7}$

2. Moeljatno menyatakan perbuatan pidana adalah perbuatan yang dilarang oleh suatu aturan hukum larangan mana disertai ancaman (sanksi) yang berupa pidana tertentu, bagi barangsiapa melarang larangan tersebut. ${ }^{8}$

3. Soedjono menyatakan bahwa kejahatan adalah perbuatan manusia yang melanggar atau bertentangan dengan apa yang ditentukan dalam kaidah hukum, tegasnya perbuatan yang melanggar larangan yang ditetapkan kaidah hukum dan tidak memenuhi atau melawan

${ }^{6}$ M. Yahya Harahap, Pembahasan Permasalahan dan Penerapan KUHAP, Jilid II,(Jakarta : Pustaka Kartini,1985). hlm. 801.

${ }^{7}$ R. Soesilo, Pokok-Pokok Hukum Pidana Peraturan Umum dan Delik-Delik Khusus, ( Bogor : Politae,1984),hlm.4.

${ }^{8}$ Moeljatno, Asas-Asas Hukum Pdana,...hlm. 60 
perintah-perintah yang telah ditetapkan dalam kaidah hukum yang berlaku dalam masyarakat. ${ }^{9}$

4. Wirjono Projodikoro menyatakan bahwa tindak pidana itu adalah suatu perbuatan yang pelakunya dapat dikenakan hukuman pidana. ${ }^{10}$ Simons, merumuskan strafbaar feit adalah suatu tindakan melanggar hukum yang dengan sengaja telah dilakukan oleh seseorang yang dapat dipertanggungjawabkan atas tindakannya yang dinyatakan sebagai dapat dihukum. ${ }^{11}$ J.E Jonkers, merumuskan peristiwa pidana ialah perbuatan yang melawan hukum (wederrechttelijk) yang berhubungan dengan kesengajaan atau kesalahan yang dilakukan oleh orang yang dapat dipertanggungjawabkan. ${ }^{12}$

\section{Jenis-Jenis Tindak Pidana}

Penggolongan jenis-jenis delik yang ada dalam KUHP terdiri dari Kejahatan (Misdriven/Recht Delicten), disusun dalam Buku II KUHP, sedangkan Pelanggaran (Over Tredingen/Wets Delicten), disusun dalam Buku III KUHP. Undang-undang hanya memberikan penggolongan kejahatan dan pelanggaran, akan tetapi tidak memberikan arti yang jelas, risalah penjelasan undang-undang.

Kejahatan adalah "Recht Delicten" yaitu perbuatan yang meskipun tidak ditentukan dalam undang-undang sebagai perbuatan pidana, dirasakan sebagai “Onrecht” sebagai perbuatan yang bertentangan dengan tata hukum. ${ }^{13}$

Secara formal kejahatan dirumuskan sebagai suatu perbuatan yang oleh negara diberi sanksi pidana. Pemberian pidana dimaksudkan untuk mengembalikan keseimbangan yang terganggu akibat perbuatan itu. Dengan patokan hukum pidana kejahatan serta pelakunya relatif dapat diketahui yaitu hlm.15.

9 Soedjono Dirjosisworo, Ilmu kejiwaan Kejahatan,( Bandung : Karya Nusantara,1977), hlm.50.

${ }_{10}$ Wirjono Projodikoro, Asas-asas Hukum Pidana di Indonesia,(Jakarta : Eresco, 1981),

${ }^{11}$ Simons, Kitab Pelajaran Hukum Pidana, (Bandung : Pioner Jaya,1992), hlm. 127.

12 J.E Jonkers, Hukum Pidana Hindia Belanda, (Bina Aksara, 1987), hlm.135.

${ }^{13}$ Moeljatno, Asas-Asas Hukum Pdana,... hlm.71. 
mereka atau barangsiapa yang terkena rumusan kaidah hukum pidana memenuhi unsur-unsur delik, ia dianggap melakukan perbuatan yang dapat dihukum. ${ }^{14}$

Selanjutnya menurut Sue Titus Reid suatu perumusan tentang kejahatan maka perlu diperhatikan adalah antara lain:

1). Kejahatan adalah suatu tindakan sengaja (Omissi) dalam pengertian ini seseorang tidak dapat dihukum karena pikirannya melainkan harus ada suatu tindakan atau kealpaan dalam bertindak. Kegagalan untuk dapat bertindak dapat juga merupakan kejahatan, jika terdapat suatu kewajiban hukum untuk bertindak dalam kasus tertentu, disamping itu ada niat jahat (Crimminal Intent Mens Rea),

2). Merupakan pelanggaran hukum pidana.

3). Dilakukan tanpa adanya suatu pembelaan atau pembenaran yang diakui secara hukum.

4). Diberikan sanksi oleh negara sebagai suatu kejahatan atau pelanggaran. ${ }^{15}$

Beberapa definisi kejahatan diatas pada dasarnya dapat diketahui kejahatan adalah suatu bentuk perbuatan dan tingkah laku yang melanggar hukum dan perundang-undangan lain serta melanggar norma sosial sehingga masyarakat menentangnya. KUHP tidak memberikan pengertian secara tegas tentang pengertian kejahatan namun dalam kaitannya dengan kejahatan dapat kita simpulkan bahwa semua perbuatan yang disebutkan dalam Buku ke II KUHP adalah kejahatan dan perbuatan lain secara tegas dinyatakan sebagai kejahatan dalam undang-undang tertentu diluar KUHP.

1) Berdasarkan pengertian kejahatan diatas dapat diketahui bahwa Pelanggaran unsur-unsur dari kejahatan itu terdiri dari:

a). Suatu perbuatan yang dilakukan dengan sengaja/culfa,

b). Pelanggaran terhadap hukum pidana,

c). Tanpa ada alasan pembenar dan alasan pemaaf,

${ }^{14}$ Soedjono Dirjosisworo, Ilmu kejiwaan,.. hlm. 12

${ }^{15} \mathrm{Op}$ Cit, Soerjono Soekanto. hlm. 84. 
d). Dikenakan sanksi pidana maupun mampu dipertanggungjawabkan.

Pelanggaran adalah "Wets Delicten" yaitu perbuatan-perbuatan yang sifat hukumnya baru dapat diketahui setelah adanya undang-undang yang menyatakan demikian. ${ }^{16}$ Perbedaan antara kejahatan dan pelanggaran dalam KUHP ada kecenderungan untuk mengikuti pandangan kuantitatif. Beberapa ketentuan KUHP yang mengandung ukuran secara kuantitatif adalah:

1). Percobaan / pembantuan dalam pelanggaran tidak dipidana, sedangkan kejahatan dapat dipidana.

2). Daluwarsa bagi pelanggaran ditentukan lebih pendek dibanding dengan kejahatan.

3). Kewenangan menuntut pelanggaran menjadi hapus apabila telah dibayar maksimum denda dan biaya perkara sebagai sistem penebusan.

4). Dalam hal terjadi perbarengan atas pelanggaran berlaku sistem pidana kumulasi murni yang tiap-tiap pelanggaran dijatuhi pidana sendirisendiri.

5). Dalam hal perampasan barang kerena pelanggaran hanya boleh dilakukan apabila tidak ditentukan dengan tegas oleh undang-undang. ${ }^{17}$

Dari uraian di atas dapat diketahui unsur dari pelanggaran adalah: pertama, Perbuatan; kedua, Melanggar hukum; ketiga, Ditentukan oleh UndangUndang; keempat, Dapat dipertanggungjawabkan.

Berdasarkan perbedaan diatas dapat diketahui bahwa kejahatan diatur dalam buku II KUHP sedangkan Pelanggaran diatur dalam Buku III KUHP. Ancaman sanksi pidana bagi kejahatan lebih berat ancaman pidananya jika dibandingkan dengan pelanggaran, karena dilihat dari sifat dan hakekat dari perbuatan itu dalam masyarakat, dimana kejahatan mempunyai dampak yang lebih buruk dibandingkan dengan pelanggaran.

Pada perkembangannya jenis-jenis tindak pidana dibagi menjadi tindak 
pidana umum dan tindak pidana khusus. Tindak pidana secara umum adalah tindak pidana yang segala ketentuannya diatur dalam ketentuan yang terdapat pada Kitab Undang-Undang Hukum Pidana, sedangkan tindak pidana khusus adalah tindak pidana yang ketentuannya diatur secara khusus dengan Undangundang tersendiri (tidak terdapat dalam KUHP contohnya : Undang-Undang Nomor 22 Tahun 1997 Tentang Narkotika, Undang Undang Nomor 5 Tahun 1997 Tentang Psikotropika, Undang-Undang Nomor 20 Tahun 2001 tentang Perubahan atas Undang-Undang Nomor 31 Tahun 1999 tentang Pemberantasan Tindak Pidana Korupsi dan lain sebagainya.

\section{Unsur-Unsur Tindak Pidana}

Mengetahui unsur-unsur tindak pidana sangat penting untuk dibuktikan melalui suatu proses sistem peradilan pidana, merupakan hal pemeriksaan dipersidangan, apabila unsur-unsur itu salah satu di antaranya tidak terbukti, maka perbuatan itu bukanlah suatu tindak pidana atau kejahatan dan tersangka harus dibebaskan dari segala tuntutan hukum. Perlu kita ketahui beberapa pendapat sarjana mengenai unsur-unsur tindak pidana yaitu:

Menurut Moeljatno unsur-unsur atau elemen perbuatan pidana adalah:
a. Kelakuan dan akibat (perbuatan)
b. Hal ikhwal atau keadaan yang menyertai perbuatan.
c. Keadaan tambahan yang memberatkan pidana.
d. Unsur melawan hukum yang objektif.
e. Unsur melawan hukum yang subjektif. ${ }^{18}$

Menurut M. Bassar Sudrajad unsur-unsur yang terkandung dalam suatu delik adalah terdiri dari:
a. Unsur melawan hukum
b. Unsur merugikan masyarakat
c. Dilarang oleh aturan hukum pidana
d. Pelakunya dapat diancam pidana. ${ }^{19}$

Menurut pendapat Tresna, tindak pidana terdiri dari unsur-unsur yakni:

${ }^{18}$ Moeljatno, Asas-Asas Hukum Pdana,..hlm. 63. hlm. 78 .

19 Adami Chazawi, Pelajaran Hukum Pidana Bagian I, (Jakarta : Rajawali Pers, 2002), 

a. Perbuatan/ rangkaian perbuatan (manusia)
b. Yang bertentangan dengan peraturan perundang-undangan,
c. Diadakan tindakan penghukuman. ${ }^{20}$

Moeljatno membedakan unsur tindak pidana berdasarkan perbuatan dan pelaku dapat dibagi dalam 2 bagian yaitu:

1. Unsur Subjektif berupa :

a). Perbuatan manusia.

b). Mengandung unsur kesalahan.

2. Unsur objektif, berupa :

c). Bersifat melawan hukum

d). Ada aturannya. ${ }^{21}$

Berdasarkan uraian tersebut di atas dapat dianalisa bahwa penjabaran unsur tindak pidana dilakukan untuk menjerat seseorang yang melakukan tindak pidana. Pelaku tindak pidana hanya dapat dipidana karena telah melakukan suatu tindak pidana, apabila jelas telah memenuhi unsur-unsur didalamnya yaitu unsur perbuatan, melawan hukum, kesalahan, dan dapat pertanggungjawabkan.

\section{E. Legal Reasoning.}

Pengertian sederhana Legal Reasoning adalah penalaran tentang hukum yaitu pencarian "reason" tentang hukum atau pencarian dasar tentang bagaimana seorang hakim memutuskan perkara/kasus hukum. Namun pengertian sederhana ini menjadi tidak lagi sederhana apabila pertanyaan dilanjutkan kepada apakah yang dimaksud dengan hukum dan bagaimana sebenarnya atau seharusnya seorang hakim memutuskan suatu perkara/kasus hukum. ${ }^{22}$ Pengertian lainnya yang sering diberikan kepada Legal Reasoning adalah suatu kegiatan untuk mencari dasar hukum yang terdapat di dalam suatu peristiwa hukum, baik yang merupakan perbuatan hukum (perjanjian, transaksi perdagangan, dll) ataupun

${ }^{20}$ Adami Chazawi, Pelajaran Hukum,.. hlm.80.

${ }^{21}$ Moeljatno, Asas-Asas Hukum Pdana,.. hlm. 64. hlm.85.

${ }^{22}$ Bagir Manan, Ilmuan Dan Penegak Hukum, (Jakarta : Mahkamah Agung, 2008), 
yang merupakan kasus pelanggaran hukum (pidana, perdata, ataupun administratif) dan memasukkannya ke dalam peraturan hukum yang ada. ${ }^{23}$

Bagi para hakim, legal reasoning ini berguna dalam mengambil pertimbangan untuk memutuskan suatu kasus. Sedangkan bagi para praktisi hukum legal reasoning ini berguna untuk mencari dasar bagi suatu peristiwa atau perbuatan hukum dengan tujuan untuk menghindari terjadinya pelanggaran hukum dikemudian hari dan untuk menjadi bahan argumentasi apabila terjadi sengketa mengenai peristiwa ataupun perbuatan hukum tersebut. Bagi para penyusun undang-undang dan peraturan, legal reasoning ini berguna untuk mencari dasar mengapa suatu undang-undang disusun dan mengapa suatu peraturan perlu dikeluarkan. Sedangkan bagi pelaksana, legal reasoning ini berguna untuk mencari pengertian yang mendalam tentang suatu undang-undang atau peraturan agar tidak hanya menjalankan tanpa mengerti maksud dan tujuannya yang hakiki.

Beberapa ahli hukum memformulasi tentang legal reasoning sebagaimana disebutkan di atas mengandung pengertian yang ambigu mengenai apakah legal reasoning adalah reasoning tentang hukum, yaitu apakah reasoning tersebut mengenai: (i) reasoning untuk mencari dasar tentang substansi hukum yang ada saat ini, atau (ii) reasoning yang diambil dari substansi hukum yang ada itu yang harus diterapkan pada putusan yang harus diambil terhadap perkara yang dihadapkan kepada hakim saat ini. Para ahli juga berbeda pandangan mengenai formulasi tentang bagaimana hakim memutuskan perkara, yang menurut mereka mengandung juga ambigu, yaitu apakah dalam memutus perkara, hakim harus mencari reasoning dari substansi hukum positif yang ada mengenai kasus tersebut ataukah hakim harus mempertimbangkan semua aspek yang ada termasuk isu mengenai moral dan lain-lain. Dengan perbedaan ini para ahli teori hukum mengambil tiga pengertian tentang legal reasoning, yaitu:

1. Reasoning untuk mencari substansi hukum untuk diterapkan dalam masalah yang sedang terjadi.

\footnotetext{
${ }^{23}$ Bagir Manan, Ilmuan Dan Penegak Hukum,..hlm 76
} 
2. Reasoning dari substansi hukum yang ada untuk diterapkan terhadap putusan yang harus diambil atas suatu perkara yang terjadi.

3. Reasoning tentang putusan yang harus diambil oleh hakim dalam suatu perkara, dengan mempertimbangkan semua aspek. ${ }^{24}$

Berdasarkan Undang-undang Nomor 48 Tahun 2009 tentang Kekuasaan Kehakiman (selanjutnya disebut UU Kekuasaan Kehakiman), hakim secara fungsional menjalankan kekuasaan kehakiman. Dengan ungkapan lain, hakim menjalankan fungsi mengadili (menyelenggarakan peradilan guna menegakkan hukum dan keadilan berdasarkan Pancasila). Dalam menjalankan fungsinya tersebut, hakim sangat terikat dengan ketentuan Pasal 5 ayat (1) UU Kekuasaan Kehakiman, yang menegaskan bahwa "Pengadilan mengadili menurut hukum dengan tidak membeda-bedakan orang". Ketentuan tersebut, khususnya mengenai frasa "mengadili menurut hukum" telah membentuk paradigma dalam pengambilan putusan oleh hakim dalam mengadili. Menurut Bagir Manan, mengadili menurut hukum dapat dijabarkan dalam empat makna :

1. Mengadili menurut hukum merupakan salah satu asas mewujudkan negara berdasarkan atas hukum. Setiap putusan hakim harus mempunyai dasar hukum substantif dan prosedural yang telah ada sebelum perbuatan melawan dan pelanggaran hukum terjadi.

2. Hukum dalam mengadili menurut hukum harus diartikan luas melebihi pengertian hukum tertulis dan tidak tertulis. Hukum dalam kasus atau keadaan tertentu meliputi pengertian-pengertian yang mengikat pihak-pihak, kesusilaan yang baik dan ketertiban umum (goede zeden en openbaar orde).

3. Hukum yang hidup dalam masyarakat adalah hukum yang dipertimbangkan dalam putusan hakim, tetapi tidak selalu harus diikuti karena kemungkinan "the living law" justru harus dikesampingkan karena tidak sesuai dengan tuntutan sosial baru.

4. Sesuai dengan tradisi hukum yang berlaku, hakim wajib mengutamakan penerapan hukum tertulis, kecuali kalau akan

\footnotetext{
${ }^{24}$ Bagir Manan, Ilmuan Dan Penegak Hukum,...hlm.88
} 
menimbulkan ketidakadilan, bertentangan dengan kesusilaan, atau ketertiban umum. Hakim bukan mulut atau corong undang-undang, melainkan mulut atau corong keadilan. ${ }^{25}$

Selanjutnya dikatakan bahwa dalam praktik mengadili menurut hukum, ada tiga kemungkinan peran hakim menerapkan hukum :

1. Hakim sekadar menjadi mulut undang-undang. Meskipun ajaran "hakim sebagai mulut undang" telah ditinggalkan, tetapi masih ada kemungkinan putusan hakim yang sekadar melekatkan ketentuan undang-undang dalam suatu peristiwa konkrit. Perbedaannya, dimasa paham legisme, hakim sebagai mulut undang-undang merupakan suatu kewajiban (imperatif). Sekarang, kalaupun hakim menjadi mulut undang-undang semata-mata karena kebebasan menemukan hukum dalam kaitan dengan suatu peristiwa konkrit. Dalam praktik, hal semacam itu akan sangat jarang terjadi.

2. Hakim sebagai penerjemah aturan hukum yang ada. Sebagai penerjemah, hakim bertugas menemukan hukum, baik melalui penafsiran, konstruksi, atau penghalusan hukum. Kewajiban ini timbul karena aturan yang ada tidak jelas, atau karena suatu peristiwa hukum tidak persis sama dengan lukisan dalam undangundang.

3. Hakim sebagai pembentuk hukum (rechtschepper, judge-made law). Hukum yang dibentuk hakim dapat berupa hukum baru, melengkapi hukum yang ada, atau memberi makna baru terhadap hukum yang sudah ada. Tugas membentuk hukum dapat terjadi karena hukum yang ada belum (cukup) mengatur, atau hukum yang ada telah usang. ${ }^{26}$

Deskripsi tersebut menunjukkan bahwa konsep "mengadili menurut hukum" melahirkan sikap yang berbeda-beda diantara hakim. Realitas tersebut tetap menggambarkan adanya perbedaan dalam memaknai "hukum". Perbedaan

${ }^{25}$ Bagir Manan, Mengadili Menurut Hukum, dalam Varia Peradilan. XX, No.238. (Jakarta : IKAHI, 2005). hlm.10.

${ }^{26}$ Bagir Manan, Mengadili Menurut Hukum,... hlm.8. 
tersebut secara historis juga terjadi dalam ranah filsafat hukum. Terlepas dari tiga kondisi praktis paradigma mengadili menurut hukum, keberadaan yurisprudensi sebagai sumber hukum, sesungguhnya dapat dimasukkan dalam pengertian hukum itu sendiri. Yurisprudensi sebagai hukum temuan atau bentukan hakim dikatakan sebagai "individual norms". 27

\section{F. Teori Kebenaran Sebagai Dasar Pertimbangan Hukum}

Suatu pertimbangan hukum putusan yang benar bila mendasarkan teori yang benar. Pertimbangan hukum putusan merupakan pertanggungjawaban hakim terhadap putusan pengadilan. Sebagai pertanggungjawaban sudah seharusnya disusun dengan mendasarkan hukum penalaran yang benar. Dalam rangka menerapkan hukum penalaran yang benar, pertimbangan hukum harus mendasarkan teori-teori yang secara umum diterima sebagai teori yang benar. Ada beberapa teori yang seharusnya digunakan landasan menyusun pertimbangan hukum, antara lain teori kebenaran dan keadilan.

Pertimbangan hukum putusan merupakan salah satu bagian terpenting dalam putusan. Sebelum sampai pada pertimbangan hukum, didahului dengan pertimbangan fakta hukum yang diperoleh dari fakta-fakta yang terungkap di persidangan. Teori kebenaran mulai diterapkan dalam persidangan sejak memeriksa berkas perkara menyidangkan perkara dan merumuskan fakta hukum. Teori kebenaran dimaksudkan sebagai landasan teoritis dan praktis dalam menyusun pertanggungjawaban putusan. Jika membuat pertimbangan hukum peraturan perundang-undangan sudah jelas, hakim tinggal melaksanakan. Jika bila aturan hukumnya tidak ada atau kurang jelas, hakim melakukan rechtsvinding ${ }^{28}$ dengan melalui konstruksi hukum dan penafsiran. Objek pemeriksaan dalam mengadili perkara pidana adalah perbuatan yang telah dilakukan terdakwa. Objek pengujian dalam mengadili perkara pidana adalah korelasi dan kausalitas antara surat dakwaan dengan fakta yang terungkap di persidangan. Jika dalam surat dakwaan menyebutkan bahwa seseorang didakwa melakukan tindak pidana sesuai dengan pasal yang didakwakan, maka fakta-fakta

${ }^{27}$ Bagir Manan, Mengadili Menurut Hukum,... hlm.8.

${ }^{28}$ Sudikno Mertokusumo \& A. Pitlo, Bab tentang Penemuan Hukum, Yogyakarta : Citra Aditya Bakti, 1993), hlm. 4. 
yang menjadi fakta hukum terdapat hubungan yaitu berkorelasi. Perbuatan terdakwa yang disebutkan dalam surat dakwaan secara realitas terdapat hubungan kausalitas dengan akibat yang timbulkan, baik kerugian material rasa sakit, cacat badan atau bahkan meninggal dunia. Selama dapat dibuktikan korelasi dan kausalitasnya, maka menurut teori koresponden adalah benar terdakwa melakukan tindak pidana sebagaimana yang didakwakan kepadanya. Dalam mengungkapkan fakta dalam persidangan, hakim tidak diperkenankan atau dilarang bertanya secara langsung, tetapi terdakwa atau saksi diminta menerangkan apa yang ia lihat sendiri dan dialami sendiri. Setelah semua alat bukti diperiksa di persidangan, maka giliran hakim mencari korelasi antar alat bukti dan hubungan kausalitasnya.

Teori merupakan pedoman yang sudah diketahui dan diakui sebagai pernyataan yang benar. Secara metodologis semua pertimbangan hukum yang didasarkan pada teori hukum, teori kebenaran dan teori keadilan, akan dapat memahami putusan pengadilan, meski kepentingannya tidak dikabulkan. Sebaliknya, jika pertimbangan hukum tidak menyebutkan teori yang dijadikan dasar secara jelas, pencari keadilan mengalami kesulitan memahami logika hukum yang dibangun dan menentukan standar atau indokator yang benar. Pada akhirnya dapat mempertanyakan kualitas putusan dan integritas moralnya meski didasarkan pada subjektifitas.

\section{G. Teori Keadilan sebagai Dasar Pertimbangan Hukum}

Pertimbangan putusan hukum pengadilan, disamping mendasarkan pada teori kebenaran, juga mendasarkan pada teori keadilan. Dalam rangka mewujudkan keadilan atau memberikan rasa keadilan kepada pencari keadilan, diperlukan pemikiran dan cara-cara serta tolok ukur keadilan yang dapat diterima pencari keadilan. Struktur masyarakat yang heterogen mempunyai tolok ukur rasa keadilan yang berbeda. Dalam sistem penegakan hukum pidana di Indonesia, tidak terdapat dengan heterogenitas aturan hukum, tetapi semua diperlakukan secara konsisten. Terjadinya amandemen UUD 1945 dan berlakunya otonomi daerah, akan berpengaruh berlakunya pluralitas aturan hukum.

Pertimbangan putusan harus dapat menunjukkan dan mendasarkan teori keadilan secara transparan. Berdasarkan keadilan normative pemeriksaan perkara 
dilakukan berdasarkan peraturan perundang-undangan. Hakim tidak diberi kebebasan mengadili perkara mendasarkan hal-hal diluar yang telah diatur dalam peraturan perundang-undangan. Dalam persidangan, pengadilan memberikan semua hak normatif diberikan oleh undang-undang. Jika ada para pihak yang tidak mampu, sedangkan menurut hukum acara yang bersangkutan harus didampingi penasehat hukum, majelis dapat menunjuk penasihat hukum atau advokat secara prodeo. KUHAP lebih berkonsentrasi memberikan hak-hak kepada terdakwa, namun tidak satu pasalpun memberikan hak kepada korban. Sistem penegakan hukum pidana dapat dilihat dalam KUHAP. Secara subatansial KUHAP berisi seperangkat aturan yang harus dipedomani oleh aparat penegak hukum dalam menangani perkara pidana. Secara formal dan substansial ketentuan KUHAP dapat dibaca secara bebas oleh siapapun. Hal ini menunjukkan bahwa prosedur penanganan dan pemeriksaan perkara dari semua tingkatan sudah transparan dalam KUHAP, sehingga dengan melaksanakan semua ketentuan KUHAP sama dengan melaksanakan keadilan prosedural. Dalam persidangan, kedudukan antara terdakwa dengan penuntut umum sederajat. Terdakwa diperlakukan secara manusiawi dan seimbang berdasarkan prinsip kesamaan.

Terdakwa diberi kesempatan untuk mengajukan keberatan atas surat dakwaan penuntut umum, dan mengajukan duplik. Dalam tahap pembuktian terdakwa diberi kesempatan menanggapi alat bukti, bahkan menyangkal dengan menggunakan hak ingkar yang diajukan dalam persidangan juga dapat mengajukan alat bukti sendiri yang meringankan. Setelah dibacakan surat tuntutan, terdakwa diberi kesempatan mengajukan pembelaan secukupnya. Setelah hakim membacakan putusan, terdakwa dan penuntut umum diberi hak yang sama untuk menanggapi putusan pengadilan antara lain; pikir-pikir, menolak atau menerima putusan. Baik terdakwa dan penuntut umum diberi hak yang sama untuk melakukan upaya hukum biasa maupun luar biasa. Berbagai hak yang diberikan berdasarkan prinsip kesamaam sebagai wujud penerapan teori keadilan komutatif (teori penerapan prinsip kesamaan).

Penerapan keadilan distributif (teori penerapan prinsip ketidaksamaan) berkaitan dengan perlakuan atau tindakan yang didasarkan pada prinsip 
ketidaksamaan. Ketidaksamaan tersebut bukan berarti melakukan diskriminasi, tetapi merupakan upaya memberikan tindakan hukum atau sanksi hukum bagi yang pantas menerimanya. Dalam pertimbangan hukum putusan, hakim menyusun konstruksi hukum dengan mendasarkan pada teori-teori hukum, menerapkan penalaran hukum secara deduktif maupun induktif, maksud dan tujuannya untuk memperoleh keyakinan terbukti tidaknya tindak pidana yang dilakukan oleh terdakwa. Dalam hal pertimbangan hukum putusan menyatakan semua unsur dakawaan terpenuhi, maka hakim menyimpulkan perbuatan terdakwa terbukti secara sah dan meyakinkan, terdakwa harus dijatuhi dengan pidana yang setimpal dengan perbuatannya.

Terdakwa yang diajukan hanya seorang, maka keadilan distributif tidak terlalu tampak. Dalam hal satu perkara terdakwanya lebih dari satu orang dan masing-masing mempunyai kualitas keterlibatannya yang berbeda, maka dalam pertimbangan hukum akan tampak keadilan distributif secara jelas. Artinya masing-masing terdakwa akan dijatuhi sanksi pidana yang berbeda pula. Dapat pula terjadi dalam hal terjadi tindak pidana yang sama, oleh karena terjadi pada daerah dan struktur serta kultur yang berbeda, maka pertimbangan hukum dan amar putusan berbeda pula. Terhadap putusan lembaga peradilan dalam perkara pidana, apabila para pihak (yaitu Jaksa Penuntut Umum dan Terdakwa) tidak puas dan hendak melawan putusan tersebut, sistem hukum acara pidana Indonesia mengakomodasikannya melalui dua jenis upaya hukum, yaitu upaya hukum biasa, dan upaya hukum luar biasa. Upaya hukum biasa meliputi pengajuan banding ke Pengadilan Tinggi (Pasal 67 dan Pasal 233 KUHAP) dan kasasi ke Mahkamah Agung (Pasal 244 KUHAP), sementara yang termasuk dalam upaya hukum luar biasa adalah Kasasi Demi Kepentingan Hukum (Pasal 259 KUHAP) dan Peninjauan Kembali Putusan Pengadilan yang telah mempunyai kekuatan hukum tetap (Pasal 263 KUHAP).

\section{H. Kebijakan Kriminal dan Sistem Peradilan Pidana}

Hakekat dari pembentukan hukum pidana adalah mengatur kehidupan manusia agar tertib dan teratur. Pembentukan hukum pidana tentu saja harus memenuhi persyaratan sehingga dapat memenuhi perkembangan sosial yang 
terjadi didalam masyarakat. Penggunaan hukum sebagai sarana perubahan sosial dimaksudkan untuk menggerakkan masyarakat agar bertingkah laku yang sesuai dengan irama dan tuntutan pembangunan, seraya meninggalkan segala sesuatu yang sudah tak perlu lagi dipertahankan. Bertalian dengan masalah tersebut menarik apa yang dikatakan oleh Mochtar Kusumaatmaja bahwa di Indonesia fungsi hukum dalam pembangunan adalah sebagai sarana pembaharuan masyarakat. ${ }^{29}$ Hal ini didasarkan pada anggapan, bahwa adanya ketertiban (stabilitas) dalam pembangunan merupakan suatu yang dipandang penting dan diperlukan. Suatu ketertiban hukum merupakan suatu ketertiban yang dipaksa (dwangorde) apabila oleh hukum suatu tindakan-tindakan tertentu tak diperkenankan, maka jika tindakan itu dilakukan, yang melakukan tindakan tersebut akan dikenakan sanksi. Menurut Kelsen prinsip dari aturan hukum adalah Jika dilakukan tindakan yang berlawanan dengan hukum, maka akan dikenakan sanksi sebagai akibat dari tindakan yang berlawanan dengan hukum tersebut. ${ }^{30}$ Hubungan antar akibat dari tindakan yang berlawanan dengan hukum dengan tindakannya itu sendiri adalah tidak sama dengan hubungan antara pemanasan sebatang besi dan akibatnya bahwa besi tersebut menjadi lebih panjang, sehingga hal tersebut bukan merupakan hukum casualitas, menurut Kelsen het onrechsgevolg wordt het onrecht toegerekend. Seberapa jauh hukum pidana dan sanksi pidana masih diperlukan untuk menanggulangi kejahatan? Kiranya terdapat beberapa pendapat mengenai hal ini. Beberapa pakar hukum pidana menolak penggunaan hukum pidana dan sanksi pidana untuk menanggulangi kejahatan, sementara beberapa pakar yang lain justru berpendapat sebaliknya.

Herbert L. Packer termasuk pakar yang menolak penggunaan hukum pidana dan sanksi pidana dengan alasan bahwa sanksi pidana merupakan peninggalan kebiadaban masa lampau. Bahkan munculnya aliran positivisme dalam kriminologi yang menganggap pelaku adalah golongan manusia yang

29 Mochtar Kusumaatmadja dan B. Arief Sidharta, Pengantar Ilmu Hukum, Suatu Pengenalan Pertama Ruang Lingkup Berlakunya Ilmu Hukum, (Bandung : Alumni, 2000).hlm 4

${ }^{30}$ Hans Kelsen, Essay in Legal and Moral Philosophy, D. Reidel Publishing Company diterjemahkan Benard Arif Sidharta,Bandung : Alumni,2002), hlm. 76. 
abnormal, menjadikan semakin kuatlah kehendak untuk menghapuskan pidana (punishment) dan menggantinya dengan treatment. ${ }^{31}$ Pakar hukum pidana yang mempunyai pandangan sebaliknya adalah pakar hukum pidana Indonesia, Roeslan Saleh dengan mengemukakan tiga alasan, yaitu:

1. Diperlukan tidaknya hukum pidana dengan sanksi hukum pidana tidak terletak pada tujuan yang hendak dicapai, melainkan pada persoalan seberapa jauh untuk mencapai tujuan itu hukum pidana dapat mempergunakan paksaan-paksaan;

2. Bahwa masih banyak pelaku kejahatan yang tidak memerlukan perawatan atau perbaikan, meski demikian masih tetap diperlukan suatu reaksi atas pelanggaran-pelanggaran norma yang telah dilakukannya itu dan tidaklah dapat dibiarkan begitu saja;

3. Bahwa pengaruh pidana bukan saja akan dirasakan oleh si penjahat, tetapi juga oleh orang lain yang tidak melakukan kejahatan. ${ }^{32}$

Menurut Barda Nawawi Arief bahwa konsep kebijakan penanggulangan kejahatan yang integral mengandung konsekuensi segala usaha yang rasional untuk menanggulangi kejahatan harus merupakan satu kesatuan yang terpadu. ${ }^{33}$ Ini berarti kebijakan untuk menanggulangi kejahatan dengan menggunakan sanksi pidana, harus pula dipadukan dengan usaha-usaha lain yang bersifat nonpenal. Usaha-usaha nonpenal ini dapat meliputi kebijakan sosial atau pembangunan nasional.

Tujuan utama dari usaha-usaha nonpenal ini adalah memperbaiki kondisikondisi sosial atau pembangunan nasional. Tujuan utama dari usaha-usaha nonpenal ini adalah memperbaiki kondisi-kondisi sosial tertentu yang secara tidak langsung mempunyai pengaruh preventif terhadap kejahatan. Dengan demikian dilihat dari sudut kriminal, keseluruhan kegiatan preventif yang nonpenal itu sebenarnya mempunyai kedudukan yang sangat strategis. Kegagalan dalam

\footnotetext{
${ }^{31}$ Herbert L Packer, The Limit of the Criminal Sanction

${ }^{32}$ Roeslan Saleh, Asas-asas hukum pidana, (Yogyakarta : Penerbit Gadjah Mada, 1962).hlm 22

${ }^{33}$ Barda Nawawi Arief, Teori-teori dan kebijakan pidana, (Penerbit Alumni, 1984).hlm 8
} 
menggarap posisi strategis ini justru akan berakibat fatal bagi usaha penanggulangan kejahatan.

Mengenai upaya nonpenal yang mempunyai kedudukan sangat strategis ini dijelaskan oleh Barda Nawawi Arief sebagai berikut bahwa upaya nonpenal ini harus ditujukan untuk menjadikan masyarakat sebagai lingkungan sosial dan lingkungan hidup yang sehat (secara materiil dan immateriil) dari faktor-faktor kriminogen. ${ }^{34}$ Ini berarti masyarakat dengan seluruh potensinya harus dijadikan sebagai faktor penangkal kejahatan atau faktor anti kriminogen yang merupakan bagian integral dari keseluruhan politik kriminal. Dilihat dari sisi upaya nonpenal ini berarti, perlu digali, dikembangkan dan dimanfaatkan seluruh potensi dukungan dan partisipasi masyarakat dalam upaya untuk mengefektifkan dan mengembangkan extra legal system atau informal and traditional system yang ada di masyarakat.

Menghadapi masalah sentral yang pertama, yang sering disebut masalah kriminalisasi, harus diperhatikan hal-hal yang pada intinya sebagai berikut:

a). Penggunaan hukum pidana harus memperhatikan tujuan pembangunan nasional, yaitu mewujudkan masyarakat adil makmur yang merata materiil dan spritual berdasarkan Pancasila, sehubungan dengan ini maka penggunaan hukum pidana bertujuan untuk menanggulangi kejahatan dan mengadakan pengugeran terhadap tindakan penanggulangan itu sendiri, demi kesejahteraan dan pengayoman masyarakat;

b). Perbuatan yang diusahakan untuk dicegah atau ditanggulangi dengan hukum pidana harus merupakan perbuatan yang tidak dikehendaki yaitu perbuatan yang mendatangkan kerugian (materiil dan atau spritual) atas warga masyarakat;

c). Penggunaan hukum pidana harus pula memperhitungkan prinsip biaya dan hasil (cost and benefit principle);

${ }^{34}$ Barda Nawawi Arief, Teori-teori dan kebijakan,...hlm 10 
d). Penggunaan hukum pidana harus pula memperhatikan kapasitas atau kemampuan daya kerja dari badan-badan penegak hukum, yaitu jangan sampai ada kelampauan beban tugas (overbelasting). ${ }^{35}$

Salah satu laporan dalam Simposium Pembaharuan Hukum Pidana Nasional pada bulan Agustus 1980 di Semarang, Barda Nawawi Arief menyatakan bahwa masalah kriminalisasi dan dekriminalisasi atas suatu perbuatan haruslah sesuai dengan politik kriminal yang dianut oleh bangsa Indonesia, yaitu sejauh mana perbuatan tersebut bertentangan atau tidak bertentangan dengan nilainilai fundamental yang berlaku dalam masyarakat dan oleh masyarakat dianggap patut atau tidak patut dihukum dalam rangka menyelenggarakan kesejahteraan masyarakat. Negara yang berdasarkan atas hukum maka bekerjanya sistem peradilan pidana (criminal justice system) menjadi prioritas utama dalam bidang penegakan hukum. Oleh sebab itu diperlukan keterpaduan antara sub sistem- sub sistem di dalam criminal justice system guna menanggulangi meningkatnya kualitas maupun kuantitas kejahatan yang terjadi ditengah-tengah masyarakat. Tujuan dari sistem peradilan pidana adalah :

1). Mencegah masyarakat menjadi korban kejahatan;

2). Menyelesaikan kasus kejahatan yang terjadi sehingga masyarakat puas bahwa keadilan telah ditegakkan dan yang bersalah dipidana;

3). Mengusahakan agar mereka yang pernah melakukan kejahatan tidak mengulangi lagi kejahatannya. ${ }^{36}$

Istilah criminal justice system menunjukkan mekanisme kerja dalam penanggulangan kejahatan dengan mempergunakan dasar pendekatan sistem. Remington dan Ohlin mengemukakan:

“...Criminal justice system dapat diartikan sebagai pemakaian pendekatan sistem terhadap mekanisme pendekatan sistem mekanisme administrasi peradilan pidana. Sebagai suatu sistem peradilan pidana merupakan suatu

35 Barda Nawawi Arief, Bunga Rampai Kebijakan Hukum Pidana. (Bandung: PT. Citra Aditya Bakti,2002), hlm. 27.

${ }^{36}$ Barda Nawawi Arief, Bunga Rampai Kebijakan,... hlm. 33. 
interaksi antara peraturan perUndang-Undangan, praktik administrasi dan sikap atau tingkah laku sosial. ${ }^{37}$

Pengertian sistem itu sendiri mengandung implikasi suatu proses interaksi yang dipersiapkan secara rasional dan dengan cara efisien untuk memberikan hasil tertentu dengan segala keterbatasan. Istilah sistem dari bahasa yunani systema yang mempunyai pengertian suatu keseluruhan yang tersusun dari sekian banyak bagian whole compounded of several parts. Secara sederhana sistem ini merupakan sekumpulan unsur-unsur yang saling berkaitan untuk mencapai tujuan bersama, yang tersusun secara teratur dan saling berhubungan dari yang rendah sampai yang tinggi. Stanford Optner menyebutkan bahwa sistem tersusun dari sekumpulan komponen yang bergerak bersama-sama untuk mencapai tujuan keseluruhan.

Hagan membedakan pengertian antara Criminal Justice Process dan Criminal Justice system yang pertama adalah setiap tahap dari suatu putusan yang menghadapkan seorang tersangka ke dalam proses yang membawanya pada penentuan pidana. ${ }^{38}$ Sedangkan yang kedua adalah interkoneksi antar keputusan dari setiap instansi yang terlibat dalam proses peradilan. Criminal justice system pada hakikatnya merupakan sistem yang berupaya menjaga keseimbangan perlindungan kepentingan, baik kepentingan negara, masyarakat maupun individu termasuk kepentingan pelaku tindak pidana dan korban kejahatan. Herbert L. Packer dalam bukunya yang terkenal The Limits of the Criminal Sanction mengemukakan bahwa ada dua model dalam Sistem Peradilan Pidana, yaitu Crime Control Model (CCM), dan Due Process Model (DPM). Kedua model tersebut yang disoroti adalah sebuah usaha yang memberi petunjuk operasional terhadap kompleksnya nilai-nilai yang mendasarinya. Hukum pidana sebagaimana disarankan oleh Herbert L. Packer adalah untuk menentukan dua sistem nilai yang berlawanan, yakni suatu ketegangan dari yang terlibat dalam hal ini, yaitu para pembuat undang-undang, hakim polisi, pengacara dan penuntut umum, dimana masing-masing nilai menjadi gambaran bagi pihak yang terlibat dan selalu

\footnotetext{
${ }^{37}$ Lloyd E. Ohlin, Frank J. Remington, Discretion in criminal justice, 1993.hlm 33

${ }^{38}$ Frank E. Hagan, Introduction to criminology: theories, methods, and criminal behavior,Penerbit Wadsworth/Thomson Learning, 2002.hlm 17
} 
bertentangan pada setiap gerak sesuai dengan waktu dan tokoh yang diwakili pada tiap proses kriminal itu. ${ }^{39}$ Adapun nilai-nilai tersebut merupakan suatu alat bantu analisis dan pertentangan kedua model itu tidak absolut dan merupakan abstraksi dari masyarakat Amerika, serta merupakan suatu cara pemeriksaan tentang bagaimana suatu perundang-undangan itu berjalan atau diterapkan dalam Peradilan Pidana di Amerika.

Kedua model tersebut di atas oleh Herbert L. Packer bukanlah label dari Das Sollen dan Das Sein, tetapi diartikan sebagai suatu hal yang mana baik dan tidak baik atau ideal, kedua model ini sebagai cara untuk memudahkan, bila membicarakan tentang tata kerja suatu proses yang dalam pelaksanaan sehari-hari melibatkan suatu rangkaian yang terjadi dalam proses peradilan pidana. Adapun nilai dasar dari kedua model itu yakni bahwa peraturan perundang-undangan itu harus ada terlebih dahulu perumusannya sebagai suatu tindak pidana yang diancam dengan pidana setiap pelanggarannya, dan sebelum seseorang dinyatakan bersalah melakukan tindak pidana, maka peraturan perundang-undangan yang dibuat itu menjadi dasar utama bagi penegak hukum dalam penerapannya. Jika ternyata terjadi pelanggaran terhadap ketentuan perundang-undangan itu, maka pelaku tindak pidana harus diproses oleh pejabat yang diberi kewenangan untuk mengabil tindakan hukum sejak tahap Penangkapan, penahanan, sampai diadakan penuntutan di Pengadilan. Kewenangan yang diberikan itu oleh Perundangundangan, maka aparat penegak hukum dalam mengambil tindakannya terhadap tersangka harus sesuai dengan peraturan perundang-undangan yang berlaku tersebut. Hak tersangka harus dihormati dan perlakuan terhadapnya tidak boleh sewenang-wenang. Penegakan hukum pidana dalam sistem peradilan pidana (criminal justice system) itu sendiri pada hakikatnya merupakan bagian dari politik kriminal yang menjadi bagian intergral dari kebijakan sosial.

Politik kriminal ini merupakan suatu usaha yang rasional dari masyarakat dalam menanggulangi kejahatan. Sehubungan dengan penegakan hukum pidana ini, maka Lawrence M. Friedman yang mengkaji dari sistem hukum (legal system) menyatakan bahwa ada tiga komponen yang ikut menentukan berfungsinya suatu

${ }^{39}$ Herbert L. Packer, The Limits of the Criminal Sanction.Penerbit Thomsn.hlm 22 
hukum (dalam hal ini hukum pidana), yaitu struktur hukum (structure), substansi hukum (substance), dan budaya hukumya (legal culture)..$^{40}$ Dari ketiga komponen inilah menurut Friedman kita dapat melakukan analisis terhadap berkerjanya hukum sebagai suatu sistem.

Uraian yang dikemukakan friedman ini tampak bahwa unsur structure dari suatu sistem hukum mencakup berbagai institusi yang diciptakan oleh sistem hukum tersebut dengan berbagai fungsinya dalam rangka bekerjanya sistem tersebut. Salah satu diantara lembaga tersebut adalah Pengadilan. Sedangkan komponen substance mencakup segala apa saja yang merupakan hasil dari structure, didalamnya termasuk norma-norma hukum baik yang berupa peraturanperaturan, keputusan-keputusan, maupun doktrin-doktrin. ${ }^{41}$

Lebih jauh Friedman mengatakan bahwa apabila sedikit direnungkan maka sistem hukum itu bukan hanya terdiri atas structure dan substance. Masih diperlukan adanya unsur ketiga untuk bekerjanya suatu sistem hukum yaitu budaya hukum. Kerangka teori dalam menelaah criminal justice system terhadap penanggulangan tindak pidana dalam tatanan legal substance dapat dilihat dari rumusan Mochtar kusumaatmadja, bahwa hukum adalah sarana pembangunan yaitu sebagai alat pembaharuan dan pembangunan.masyarakat yang merupakan alat untuk memelihara ketertiban dalam masyarakat (Law as tool of social engineering). 42

\section{Kesimpulan}

Mengingat fungsinya, sifat hukum pada dasarnya adalah konservatif, artinya hukum bersifat memelihara dan mempertahankan yang telah dicapai. Selain itu hukum harus dapat membantu proses perubahan pembangunan masyarakat tersebut. Berdasarkan teori di atas, peran criminal justice system terhadap penangulangan tindak pidana penyalahgunaan Narkoba harus didasarkan pada pencapaian usaha untuk melakukan pemberantasan dan penanggulangan peredaran gelap Narkoba dengan mengarahkan secara integrited (terpadu) seluruh

\footnotetext{
${ }^{40}$ Lawrence M. Friedmen,Discretion in criminal justice, 1993.hlm 13

${ }^{41}$ Lawrence M. Friedmen,Discretion in criminal justice,...hlm 15

42 Barda Nawawi Arief, Beberapa aspek kebijakan penegakan dan pengembangan hukum, (Citra Aditya Bakti, 1998).
} 
AL-QADHA Jurnal Hukum Islam Dan Perundang-undangan

komponen perangkat aturan kriminalisasi penyalahgunaan Narkoba dan aparatur penegak hukum dalam sistem peradilan pidana. 


\section{DAFTAR PUSTAKA}

Abdullah, Pertimbang Hukum Putusan Pengadilan, Program Pascasarjana Universitas Sunan Giri, Surabaya,2008

Abdulkadir Muhammad, Hukum dan Penelitian Hukum, PT. Citra Aditya Bakti, Bandung,2004

Abraham Abramovsky, Money Laundering and Narcotics Prosecution, Ford L, dalam Yenti Garnasih, 1986

Andi Hamzah, Kejahatan Narkotika dan Psikotropika, PT. Sinar Grafika, Jakarta,1994

Bagir Manan, Persepsi Masyarakat Mengenai Pengadilan dan Peradilan yang Baik, Varia Pengadilan, Edisi nomor 258 Mei 2007, Ikatan Hakim Indonesia, Jakarta,2007

Bagir Manan, Ilmuan dan Penegak Hukum (Kenangan Sebuah Pengabdian), Mahkamah Agung,2008

Dali Mutaiara, Tafsir K.U.H.P. (Kitab Undang-undang Hukum Pidana) Republik Indonesia (Wetboek Van Strafrech Voor Indonesie Yang Telah Diperbaharui Dengan Penjelasannya, Bintang Indonesia, Jakarta, 1962

Komariah Emong Sapardjaja, Ajaran Sifat Melawan Hukum Materiel dalam Hukum Pidana Indonesia, Mahkamah Agung RI, 2008

Laden Marpaung, Asas-Teori-Praktik Hukum Pidana, Sinar Grafika, Jakarta,2005

Moeljatno, Kitab Undang-undang Hukum Pidana, Bumi Aksara, Jakarta,1999

Otje.H.R Salman, dan Anton F.Susanto, Teori Hukum. PT. Refika Aditama, Bandung,2005

Romli Atmasasmita, Himpunan Lengkap Undang-undang Dan Peraturan Tentang Ekstradisi Kejahatan Penerbangan, Kejahatan Narkotika, Interpol, Persetujuan Kerjasama Dibidang Peradilan, Indonesia Peraturan Perundang-undangan, Bina Cipta, Bandung, 1980

Romli Atmasasmita, Tindakpidananarkotika Transnasional Dalam Sistem Hukum pidana Indonesia Transnational Narcotic Crime Within The Indonesia Criminal Law System, Citra Aditya Bakti, Bandung, 1997

R. Subekti, Kamus Hukum, Ghalia Indonesia, Jakarta, 1984 
AL-QADHA Jurnal Hukum Islam Dan Perundang-undangan

Satjipto Raharjo, Masalah Kebebasan Hakim dalam Menangani suatu Perkara Pidana, Aksara Persada Indonesia,1987

Satochid Kartanegara, Hukum Pidana, Balai Lektur Mahasiswa,2008

Satrio, Hukum Perikatan, perikatan yang lahir dari perjanjian (buku I), PT. Citra Aditya Bakti, Bandung,2005

Wirjono Prodjodikoro, Pengantar Hukum Pidana, Fuad Usfa, Moh. Najih, Tongat, Umm Press, Malang,2004

W.J.S Poerwadarminta, Kamus Besar Bahasa Indonesia, Balai Pustaka, Jakarta, 1991

Yahya Harahap, Pembahasan Permasalahan dan Penerapan KUHAP, Sinar Grafika, Jakarta,2008. 